\title{
KEBENCIAN DAN AMARAH TOKOH EKSIL DALAM CERPEN TANAH AIR DAN ASMARA DAN KEMATIAN DI PERBATASAN TIGA NEGARA KARYA MARTIN ALEIDA
}

\author{
Syahwan Alfianto Amir, Inriati Lewa, M. Syafri Badaruddin \\ Pascasarjana Bahasa Indonesia, Fakultas Ilmu Budaya Universitas Hasanuddin \\ alfiandippahatang@gmail.com \\ indriatilewa@yahoo.com \\ syafribadaruddin@gmail.com
}

\begin{abstract}
This research aims to elaborate the manifestations of hate and anger of the exile characters in the short stories of Tanah Air and Asmara dan Kematian di Perbatasan Tiga Negara by Martin Aleida. This research used qualitative analysis by using descriptive method. The technique of data collections used library research or content analysis. The result of the study shows that hate and anger of the exile characters in both short stories by Martin Aleida, according to the psychology existential by May divided into two categories. These categories come to animate the story that starring by the characters who deliberately labelled as an exile. There are two types of hate and anger in the exile characters is hate and anger of the regime and hate and anger of their self. In the short story of Tanah Air, the two categories come to affirm the occasion of a phenomenon and in the short story Asmara dan Kematian di Perbatasan Tiga Negara, only one category that begins to build the occasion of the short story. The result that the exile characters reveal their existence by showing hate and anger to the regime.
\end{abstract}

Keywords: characters, exile, literary psychology

\section{PENDAHULUAN}

Ketika membaca dua cerpen karya Martin Aleida, masing-masing berjudul Tanah Air dan Asmara dan Kematian di Perbatasan Tiga Negara, terdapat sesuatu yang dengan sengaja dilabelkan pada diri tokoh. Ada peran yang signifikan pada tokoh yang dilabeli sebagai tokoh eksil. Pelabelan pada tokoh ini menjadi daya tarik dalam mengungkap suatu fenomena yang terjadi dalam cerpen. Tokoh eksil dapat ditelusuri kehadirannya, karena tokoh diperkenalkan dengan membiarkan karakter atau penokohannya tampak melalui ucapan atau dialog, tindakan, dan penilaian narator atau tokoh lainnya. Dengan demikian, tokoh yang berfungsi sebagai perangkat penting yang melahirkan peristiwa tampak lebih unik. Tokoh eksil dalam dua cerpen tersebut merupakan hal yang menarik perhatian peneliti, karena rangkaian peristiwa yang muncul semakin menghidupkan cerita.

Tidak mudah bagi tokoh eksil untuk bertahan dalam situasi yang tidak normal dalam kehidupannya. Melalui penokohan, tokoh eksil bergerak untuk memperlihatkan eksistensinya. Eksistensi (Rokhmansyah, 2014) dapat berarti berdiri keluar dari diri pribadi. Dengan keluar dari diri pribadi, tokoh memahami dan mengerti keberadaannya. Ia ada sebagai aku yang mengerti dan bagaimana menghadapi dunia. Dengan menyadari kehadirannya, tokoh-tokoh dalam cerita akan berusaha memperbaiki diri dan tidak selesai dalam membangun dirinya.

Eksistensi tokoh-tokoh dalam dua cerpen tersebut dipaparkan sedemikian rupa berdasarkan fakta-fakta yang tampak dipinjam dari peristiwa yang terjadi dalam kehidupan nyata. Tokoh eksil menciptakan ruang untuk menunjukkan eksistensinya, 
terlebih saat berbenturan pada suatu masalah yang berefek pada sisi psikologinya. Masalah-masalah yang ada dalam cerpen dihadirkan untuk menguatkan penggambaran atas suatu fenomena. Eksistensi tokoh eksil dapat terlihat saat menumpahkan kebencian dan amarahnya atas fenomena yang melingkupinya dalam kehidupan. Penelitian ini berfokus pada aspek kebencian dan amarah tokoh eksil. Kebencian dan amarah satu kesatuan dalam teori psikologi eksistensial May.

Tokoh eksil muncul karena situasi politik yang begitu kuat ingin melanggengkan satu kekuasaan pada suatu negara. Dalam dua cerpen karya Martin Aleida, negara yang dimaksud adalah Indonesia yang saat itu telah dikuasai oleh rezim otoriter Soeharto dengan nama Orde Baru. Di masa Orde Baru, eksil telah tersebar di Eropa dan menjadi kisah pilu yang tidak pernah menemukan ujung penyelesaiannya sampai hari ini. Mudzakkir (2013) memberi pandangan, bahwa secara bahasa, eksil (exile) memiliki arti pengasingan. Dalam pengertian yang lebih luas, eksil berarti orang-orang yang karena alasan tertentu terasing dari Tanah Airnya. Memasuki periode pascakemerdekaan, eksil Indonesia adalah mereka yang terasingkan karena efek dari peristiwa gerakan 30 September 1965. Mudzakkir (2015) kemudian menegaskan, bahwa di hadapan pemerintah Orde Baru, orang-orang Indonesia yang sementara berada di luar negeri dan tidak ingin tunduk pada kepemimpinan Soeharto akan diberi cap bagian dari Partai Komunis Indonesia (PKI).

Kisah yang dipaparkan ini dengan jelas diperankan oleh tokoh, khususnya tokoh eksil. Tokoh dalam cerpen tidak berfungsi dalam situasi kosong, melainkan bergerak menciptakan dan menyikapi suatu peristiwa. Perilaku dan kejiwaan tokohtokoh yang sengaja dilabeli dalam dua cerpen karya Martin Aleida menarik minat peneliti untuk mengkajinya lebih dalam dengan tinjauan psikologi sastra. Psikologi sastra berupaya memahami tingkah laku dan pengalaman tokoh dalam kerangka yang melingkupi pengetahuan dan gambaran tentang sosok manusia.

Teori psikologi sastra yang digunakan oleh peneliti dalam penelitian ini dispesifikkan pada psikologi eksistensial model May. Analisis psikologi eksistensial bertujuan menemukan mode eksistensial tokoh, yaitu pilihan tokoh atas eksistensi dan relasinya yang terbentuk di antara dirinya, tokoh lain, dan dunia eksternalnya. Tinjauan ini sangat relevan digunakan peneliti untuk mengkaji objek secara ilmiah berdasarkan permasalahan yang telah dipaparkan.

Dari uraian latar belakang di atas, maka rumusan masalah dalam penelitian ini adalah bagaimana wujud kebencian dan amarah tokoh eksil dalam cerpen Tanah Air dan Asmara dan Kematian di Perbatasan Tiga Negara karya Martin Aleida?

Tujuan dari penelitian ini adalah menguraikan wujud kebencian dan amarah tokoh eksil dalam cerpen Tanah Air dan Asmara dan Kematian di Perbatasan Tiga Negara karya Martin Aleida.

\section{KAJIAN TEORETIS}

\section{Tokoh}

Tokoh adalah seseorang yang melahirkan peristiwa dalam cerita. Dilihat dari aspek keterlibatannya dalam rangkaian cerita, secara garis besar, tokoh dalam cerpen dibedakan menjadi dua, yaitu tokoh sentral dan tokoh periferal. Tokoh sentral dapat ditinjau dengan tiga cara, yaitu (a) tokoh yang paling banyak terlibat untuk menguak tema, makna, dan pesan (b) tokoh yang paling banyak berinteraksi dengan tokoh lainnya, dan (c) tokoh yang paling banyak membutuhkan waktu penceritaan. Sedangkan tokoh periferal adalah tokoh bawaan sebagai bumbu tambahan dalam cerita (Sayuti, 2017). 


\section{7 | JURNAL ILMU BUDAYA}

Volume 8, Nomor 2, 2020

Tokoh juga dapat dibedakan dengan melihat watak atau karakternya. Terma watak atau karakter, menurut Stanton (2007), biasanya dilihat dalam dua bagian. Bagian pertama, watak merujuk pada suatu individu yang muncul dalam cerpen. Bagian kedua, watak merujuk pada penggabungan dari bermacam keperluan, emosi, kehendak, dan prinsip moralitas dari individu tersebut.

Penting dimengerti secara jelas, bahwa tokoh-tokoh dalam cerpen adalah hasil rekaan dan imajinasi dari pengarang. Hanya pengarang yang dapat mengenal secara konkret tokoh-tokoh tersebut. Pengarang membentuknya dengan berbagai teknik yang dimiliki atau dikuasainya. Cara pengarang dalam memperkenalkan tokoh-tokoh dalam cerpen inilah yang disebut dengan penokohan. Dalam hal ini, setidaknya dikenal dua macam metode dalam membentuk penokohan, yaitu metode analitik dan metode dramatik.

Metode analitik adalah metode yang dilakukan oleh pengarang dalam memperkenalkan tokoh-tokoh ceritanya kepada pembaca dengan melukiskan watak tokoh secara langsung. Dalam metode ini, pengarang langsung menyebutkan sifatsifat tokoh. Misalnya, pemarah, pantang menyerah, baik hati, sombong, dan selalu berburuk sangka. Sedangkan, metode dramatik adalah metode yang dilakukan oleh pengarang dalam memperkenalkan tokoh-tokoh ceritanya kepada pembaca dengan tidak langsung melukiskan watak tokoh. Dalam metode ini, tokoh-tokoh tidak dinarasikan secara langsung, tetapi penokohannya dibiarkan muncul melalui ucapan, tindakan, dan penilaian tokoh lainnya.

\section{Eksil}

Dalam esainya, Situmorang (2014) mengatakan, bahwa istilah eksil sendiri berasal dari bahasa Latin, yaitu "exsilium" yang berarti pembuangan dan "exsul" yang berarti seseorang yang dibuang. Dalam bahasa Inggris dinamakan "exile", yang kemudian diindonesiakan dengan sebutan "eksil". Eksil memiliki tiga pengertian. Pertama, ketidakhadiran atau absensi yang begitu panjang, terjadi karena keterpaksaan untuk menjauh dari tempat tinggal atau tempat lahir. Kedua, pembuangan yang dilakukan secara resmi oleh negara kepada rakyatnya. Ketiga, individu yang sengaja dibuang ataupun hidup di luar dari negerinya sendiri.

Dari pengertian mengenai eksil di atas, Situmorang menegaskan, bahwa faktor pemindahan geografis dari tempat tinggal atau tempat lahir ke sebuah tempat yang asing atau baru adalah hal utama yang menciptakan suatu kondisi yang dialami oleh seseorang sehingga disebut sebagai eksil. Pemindahan geografis ini terjadi, karena negara secara resmi melakukannya di balik kepentingan politik atau hal tersebut terjadi, karena keputusan pribadi seseorang yang tidak ingin tunduk pada kekuasaan. Di samping itu, Loir (2018) memberi pandangan singkat, bahwa eksil adalah seseorang yang secara kebetulan berada di negeri asing pada saat putsch (memaksakan kehendak pada pemerintah, bukan menggulingkan) tahun 1965 terjadi dan terpaksa tetap tinggal di luar negeri selama berpuluh-puluh tahun.

Aleida (2017) juga mengatakan, bahwa eksil biasa diartikan orang yang lenyap Tanah Airnya. Suatu fenomena yang terjadi di Indonesia dan sudah lama ada jauh sebelum Gus Dur menggambarkan orang tersebut sebagai orang klayaban yang mengembara di berbagai negara di Eropa Barat. Eksil bukan diaspora. Eksil berpindah-pindah menyeberangi berbagai batas negara tanpa paspor, semua itu terjadi untuk menghindari rezim Soeharto.

\section{Psikologi Sastra}

Psikologi sastra terkonsentrasi pada masalah tokoh yang menggambarkan 


\section{8 | JURNAL ILMU BUDAYA}

Volume 8, Nomor 2, 2020

kejiwaan. Tidak sekadar jiwa pribadi yang muncul dalam sastra, tetapi juga dapat merepresentasikan jiwa pribadi lainnya (Minderop, 2010). Aminuddin (1995) menegaskan, bahwa karya sastra dan psikologi mempunyai hubungan yang erat, yaitu sama-sama menelusuri kejiwaan seseorang. Perbedaannya terletak pada gejala kejiwaan. Dalam karya sastra, gejala kejiwaannya adalah manusia imajiner, sedangkan dalam psikologi, gejala kejiwaannya adalah manusia yang nyata. Selain itu, antara sastra dan psikologi mempunyai hubungan saling melengkapi untuk memperoleh pemahaman yang mendalam tentang jiwa manusia, karena apa yang terungkap oleh pengarang tidak dapat diamati psikologi atau sebaliknya.

Wellek dan Warren (2014) memberikan pandangan, bahwa psikologi sastra memiliki empat pengertian. Pertama, suatu studi psikologi pengarang sebagai tipe atau sebagai pribadi. Kedua, suatu studi mengenai proses kreatif. Ketiga, suatu studi tentang hukum-hukum psikologi yang diterapkan dalam karya sastra. Keempat, suatu studi yang melihat

\begin{tabular}{|c|l|l|}
\hline No. & Psikologi & \multicolumn{1}{c|}{ Keterangan } \\
\hline 1. & Psikologi kepribadian & $\begin{array}{l}\text { Psikologi ini berkait dengan kepribadian (eksistensial, } \\
\text { humanisme, behaviorisme, dan psikoanalisis. }\end{array}$ \\
\hline 2. & Psikologi abnormal & $\begin{array}{l}\text { Psikologi yang berkait dengan dunia anomali dan } \\
\text { abnormalitas }\end{array}$ \\
\hline 3. & Psikologi agama/sufi & Psikologi yang berkait dengan agama/keyakinan. \\
\hline 4. & Psikologi lingkungan & Psikologi yang konsern pada lingkungan. \\
\hline 5. & Psikologi antropologi & Psikologi yang konsern pada budaya masyarakat \\
\hline 6. & Psikologi mimpi & Psikologi yang konsern pada dunia mimpi \\
\hline 7. & Psikologi komunitas & Psikologi yang konsern pada kelompok-kelompok \\
\hline 8. & Psikologi interdisipliner & $\begin{array}{l}\text { Psikologi yang konsern pada interdispliner ilmu } \\
\text { psikologi dengan bidang yang lain }\end{array}$ \\
\hline
\end{tabular}

dampak sastra (psikologi) kepada pembaca.

Darma (2019) lebih mengerucutkan tiga alasan psikologi masuk dalam kajian sastra, yaitu:

1. Untuk mengetahui motivasi dan perilaku para tokoh dalam karya sastra. Langsung atau tidak langsung, perilaku para tokoh dalam karya sastra terlihat juga dalam kehidupan nyata.

2. Untuk mengetahui motivasi dan perilaku pengarang.

3. Untuk mengetahui respons atau reaksi psikologi para pembaca.

Psikologi sastra pada hakikatnya menceritakan mengenai kepribadian tokoh atau melukiskan psikis tokoh yang menentukan tingkah laku dan pemikirannya yang khas. Sastra digunakan oleh pengarang sebagai medium untuk menembus batin pribadi suatu individu yang direpresentasikan pada tokoh untuk diangkat ke permukaan, sehingga dapat dimengerti oleh pembaca, bahwa ada aspek kejiwaan dari para tokoh yang ditampilkan oleh pengarang (Hikma).

\section{Berikut tabel yang memperlihatkan studi psikologi dalam studi sastra (Ahmadi, 2019).}




\section{Psikologi Eksistensial May}

Di dalam teori psikologi eksistensial May, salah satu aspek penting untuk melihat eksistensi tokoh adalah kebencian dan amarah. May dan Basescu (1968: 78) menegaskan, bahwa psikologi eksistensial adalah sebuah psikologi komprehensif yang bertujuan melihat perilaku manusia dalam keseluruhan hidupnya dan melihat perbedaan sudut pandang individu (tokoh) dalam menyikapi sesuatu hal dalam dunia. May (dalam Misiak dan Sexton, 2009) juga menegaskan, bahwa psikologi eksistensial adalah suatu upaya memahami manusia yang mengalami dan yang menjadi sasaran pengalaman. Psikologi eksistensial diilhami oleh eksistensialisme, suatu gerakan yang memusatkan penyelidikannya kepada manusia sebagai pribadi individual dan sebagai sosok yang ada-dalam-dunia (tanda sambung menunjukkan ketidakterpisahan antara manusia dan dunianya).

Kebencian dan amarah sering menjadi satu-satunya jalan bagi orang untuk menghindar dari bunuh diri secara psikologis dan spiritual. Kebencian dan amarah sampai batas tertentu berfungsi sebagai penjaga harga diri, makna akan identitas diri sendiri, sebagai seorang pribadi. Dalam kehidupan bangsa-bangsa, orang-orang yang dijajah masih dapat mengatakan secara diam-diam kepada para penjajah mereka, "Kalian telah menaklukkan kami, tetapi kami masih punya hak untuk membenci kalian." Dalam kasus-kasus neurosis atau psikosis berat, sering terlihat dengan jelas bahwa seseorang, digerakkan oleh bentengbenteng pertahanan diri akibat dari kondisi-kondisi tidak menguntungkan di tahap perkembangan awal, tetapi merawat kebenciannya dalam sebuah benteng batin guna mempertahankan harga diri dan martabatnya (May, 2019).

\section{METODE PENELITIAN}

Penelitian ini tetap mengacu pada teori struktural. Struktural digunakan untuk menelusuri kehadiran tokoh dan penokohan dalam cerita. Dari aspek intrinsik teori struktural, kemudian dilanjutkan dengan mengungkap aspek ekstrinsik melalui tinjauan psikologi sastra, khususnya psikologi eksistensial model May. Psikologi eksistensial adalah suatu pendekatan yang mempelajari perilaku manusia, khususnya hubungan subjektifnya dengan dirinya sendiri, dengan sesamanya, dan dengan dunianya. Psikologi eksistensial meneliti tokoh sebagai makhluk yang memiliki pikiran dan kemampuan berinteraksi secara personal maupun sosial di kehidupan yang terdapat dalam karya sastra. Pendekatan ini digunakan peneliti dalam mengkaji kebencian dan amarah tokoh eksil dalam dua cerpen karya Martin Aleida.

Dari pemaparan di atas, jenis penelitian yang relevan adalah penelitian kualitatif dengan metode deskriptif. Faruk (2012) memberi penjelasan, bahwa penelitian kualitatif adalah penelitian yang tidak mengedepankan angka-angka, tetapi mengedepankan kedalaman penghayatan dan konsep yang sedang dikaji secara empiris. Tahapan ini menghasilkan suatu temuan melalui data-data yang dikumpulkan dari beragam sarana, seperti dokumen atau arsip dan tes. Sedangkan, metode deskriptif adalah metode yang dilakukan dengan cara mendeskripsikan suatu objek material yang diteliti secara kualitatif, kemudian disusul dengan suatu analisis (Hasyim, et al, 2020, Intan, 2018).

Teknik pengumpulan data yang digunakan dalam penelitian ini adalah studi kepustakaan (library research) atau disebut dengan analisis isi (content analysis). Menurut Yin (2000: 109), kegiatan dalam analisis isi ini tidak hanya mencatat isi penting yang tersurat dalam teks, tetapi juga memahami makna yang 
tersirat dalam teks dengan teliti dan kritis. Teknik ini dilakukan, agar peneliti mengetahui data penelitian yang benarbenar diperlukan untuk menjawab pertanyaan penelitian. Adapun langkahlangkah pengumpulan data yaitu menentukan fokus kajian dalam dua cerpen karya Martin Aleida, membaca secara cermat dan berulang terhadap objek yang diteliti, mencatat dan mengidentifikasi data-data berdasarkan masalah yang telah dirumuskan, mengklasifikasikan data-data, dan terakhir, menafsir dan menganalisis data-data.

\section{HASIL DAN PEMBAHASAN}

Penelitian kebencian dan amarah tokoh eksil dalam dua cerpen karya Martin Aleida dapat dilihat dari tabel berikut.

\begin{tabular}{|l|l|l|}
\hline $\begin{array}{l}\text { Psikologi Eksistensial } \\
\text { May }\end{array}$ & $\begin{array}{c}\text { Tokoh Eksil dalam } \\
\text { Cerpen Tanah Air }(\text { TA })\end{array}$ & $\begin{array}{c}\text { Tokoh Eksil dalam } \\
\text { Cerpen Asmara dan } \\
\text { Kematian di Perbatasan } \\
\text { Tiga Negara (ADKPTN) }\end{array}$ \\
\hline Kebencian dan Amarah & $\begin{array}{l}\text { - Kebencian dan Amarah } \\
\text { kepada Rezim } \\
\text { Kebencian dan Amarah } \\
\text { kepada Diri }\end{array}$ & $\begin{array}{l}\text { Kebencian dan Amarah } \\
\text { kepada Rezim }\end{array}$ \\
\hline
\end{tabular}

\section{Kebencian dan Amarah pada Tokoh Eksil dalam Cerpen Tanah Air (TA) a. Tokoh Ang}

Tokoh adalah seseorang yang kehadirannya sangat penting dalam cerita. Tokoh berperan mengatur jalannya alur dan konflik. Tokoh eksil adalah tokoh yang dalam cerita dicirikan sebagai orangorang yang bukan diaspora, melainkan orang-orang yang hak kewarganegaraannya dicabut oleh sebuah rezim atau penguasa yang otoriter. Pelabelan tokoh Ang sebagai tokoh eksil dalam cerpen $T A$ secara eksplisit dapat dilihat dari data berikut.

Dari kawan-kawannya sesama pelarian yang tak bisa pulang karena paspor mereka dirampas penguasa baru di tanah yang kutinggalkan, kudengar dia merasa sangat bersalah (Aleida, 2019).

Dari kutipan di atas dapat diidentifikasi, bahwa paspor tokoh Ang dirampas dalam artian dicabut hak kewarganegaraannya. Dibawa kekuasaan, orang-orang berpaspor Indonesia yang berada di luar negeri (baik untuk belajar, bekerja, berlibur, dll.) yang tidak setuju dan tunduk pada pemerintah yang berkuasa, harus menanggung nasib dengan merelakan haknya dan identitasnya dihapus.

Dalam cerpen $T A$, ada dua tokoh sentral. Kedua tokoh ini berperan melahirkan detail peristiwa. Tokoh aku pertama tunggal adalah tokoh An Sui, sang istri yang bergerak mendeskripsikan cerita, sedangkan tokoh dia ketiga tunggal adalah tokoh Ang, sang suami sebagai eksil yang menderita karena sikap politisnya tidak menginginkan sebuah rezim otoriter berkuasa di Tanah Airnya.

\section{b. Kebencian dan Amarah}

\section{Kebencian dan Amarah kepada Rezim}

Setiap orang pasti memiliki alasan untuk membenci dan marah. Penyebab seseorang kadang benci dan marah, karena merasa dikecewakan, dikhianati atau disakiti. Tidak ada yang bisa melarang seseorang untuk melakukan hal tersebut. Namun, kata May (2019), kebencian dan amarah sampai batas tertentu berfungsi sebagai penjaga harga diri, makna akan 


\section{1 | JURNAL ILMU BUDAYA}

Volume 8, Nomor 2, 2020

identitas diri sendiri, sebagai seorang pribadi.

Tokoh Ang tampak dari kutipan berikut, memunculkan perasaan benci dan marahnya, karena merasa dikhianati oleh tata pemerintahan atau rezim yang berkuasa. Konsistensi menjaga harga diri yang dijunjung oleh tokoh Ang dengan sadar ia lakukan. Dapat dilihat dari kutipan berikut.

"Juallah semuanya, jangan tinggalkan sepeser pun di negeri yang dikuasai fasis itu. Terbanglah kemari. Tanahmu. Tanahku, walau segenggam, menunggu di sini." (Aleida, 2019).

Tokoh Ang dalam cerpen $T A$ menganggap, bahwa kekuasaan dalam hal ini kepemimpinan Soeharto adalah seorang yang fasis. Fasisme adalah sistem pemerintahan nasionalis otoriter. Tokoh Ang tentu saja merasa, bahwa Soeharto adalah pemimpin yang otoriter pada negaranya. Suara atau pendapat kritis masyarakat terhadap pemerintah bakal dibungkam habis-habisan.

Pemerintahan fasis memang sering kali seorang diktator yang anggota pemerintahannya dari militer. Pemerintahan-pemerintahan fasis pun berakar pada nilai sentral yang sama, yaitu anti komunis, anti liberal, dan anti konservatisme. Nilai-nilai ini yang ditentang tokoh Ang, sehingga ia tidak ingin tunduk dan patuh pada pemerintahan Soeharto. Risikonya berat dan ia rasa dampaknya, yaitu tubuhnya terpisah dari negeri asal.

\section{Kebencian dan Amarah kepada Diri}

Kebencian dan amarah tidak terbatas pada respons seseorang mengenai kehidupan yang terjadi dari lingkungan eksternalnya. Untuk persoalan yang menyangkut pilihan terhadap diri sendiri, terkadang diri sendiri terlunta-lunta melakukan kontrol. Kebencian dan amarah

\section{E-ISSN: 2621-5101 P-ISSN:2354-7294}

tokoh Ang tidak hanya tampakkan pada negara, tetapi juga pada dirinya sendiri. Berikut kutipannya.

Dari kawan-kawannya sesama pelarian yang tak bisa pulang karena paspor mereka dirampas penguasa baru di tanah yang kutinggalkan, kudengar dia merasa sangat bersalah. Mengutuki dirinya sebagai seorang ayah yang keji, karena tidak membesarkan, apalagi menyekolahkan, anak tunggal kami (Aleida, 2019).

Bercakap-cakap di taman, di meja makan, di tempat tidur, dia tak habis-habisnya mengutuk dirinya sendiri. Karena ucapan anaknya yang masih kecil, bahwa dia bukan seorang ayah yang bertanggung jawab (Aleida, 2019).

Dalam cerpen $T A$, tokoh Ang mengalami banyak tekanan dan masalah, karena pilihan ideologi. Dua kutipan di atas menunjukkan, bahwa kebencian dan amarah tokoh Ang pada dirinya terjadi karena sebagai ayah, ia merasa tidak ikut membesarkan, menyekolahkan, dan bertanggung jawab pada anak tunggalnya. Ia bersalah dan mengutuk dirinya sendiri, sebab ada peran besar yang ia tinggalkan dalam keluarga. Keputusannya membenci rezim telah berdampak pada kehidupan keluarganya. Hal tersebut juga berimbas pada dirinya.

\section{Kebencian dan Amarah pada Tokoh Eksil dalam Cerpen Asmara dan Kematian di Perbatasan Tiga Negara (ADKPTN)}

\section{a. Tokoh Aku dan Istri}

Tokoh yang diberi label tertentu, dapat ditelusuri dengan melihat tokoh itu sendiri dan penokohannya. Pelabelan tokoh Aku dan Istri sebagai tokoh eksil dalam cerpen $A D K P T N$ dinyatakan dari kutipan berikut.

Tonggak itu menjadi saksi bagi kekuatan cinta. Antara aku dan istriku. Dan bahwa 


\section{2 | JURNAL ILMU BUDAYA}

Volume 8, Nomor 2, 2020

cinta itu melebihi kesadaran kami terhadap Tanah Air, di mana sebuah kekuasaan sedang melancarkan teror pada warganya sendiri, menyusul bencana politik setengah abad lalu, yang menyebabkan ratusan ribu dibunuh, sementara kami yang sedang berada di luar negeri tak bisa pulang. Kecuali mau mati. Atau paling tidak siap dipenjarakan (Aleida, 2019).

Orang-orang yang terbuang, yang tak bisa pulang, dihadang senjata dan penjara, seperti aku ini, masih muda-muda pada waktu itu. Romantisme ada di mana-mana, tidak hanya di taman-taman kota atau mal. Juga ada dalam keterasingan yang tidak pernah kami bayangkan (Aleida, 2019).

Kata kami pada dua kutipan di atas merujuk pada tokoh Aku dan Istri sebagai eksil. Tokoh Aku berperan sebagai narator dalam mendeskripsikan peristiwa masa lalu yang dialaminya bersama Istri. Kenangan terhadap otoriternya rezim Soeharto terekam kembali, saat tokoh Aku berbincang dengan cucunya menjelaskan mengenai riwayat oleh-oleh semacam koin yang ia peroleh di titik perjumpaan batas tiga negara, yaitu Belanda, Jerman, dan Belgia.

Tokoh Aku yang juga disapa Atok oleh cucunya ini, di akhir cerita baru tersadar, izin tinggal atas kunjungan di Tanah Airnya, tanah kelahirannya akan berakhir tiga hari lagi. Begitulah, tokoh $\mathrm{Aku}$ dan Istri memilih tinggal dan berpaspor luar negeri, karena efek bencana politik di Indonesia memunculkan penguasa zalim yang tidak mereka sepakati. Saat Orde Baru berlangsung, setiap waktu ada teror terjadi dan tidak segan membunuh warganya sendiri yang dianggap berhaluan dengan cita-cita penguasa.

\section{b. Kebencian dan Amarah}

Pemerintah yang totaliter, menyediakan sasaran-sasaran kebencian bagi rakyat mereka untuk menutupi kenyataan, bahwa mereka telah merampas kebebasan rakyat mereka (May, 2019). Tokoh Aku dan Istri adalah korban dari rezim yang mereka rasa totaliter terhadap rakyat. Pilihan politik yang tidak selaras harus mengalami pembungkaman.

Tapi, pelarian, apalagi yang jadi korban dari satu kekuasaan yang tak punya hati, membuat manusia menjadi cerdas tak terduga (Aleida, 2019: 32).

Kematian yang tidak bisa kami bayangkan lima puluh tahun yang lalu, manakala kekuasaan yang zalim membiarkan, kalau bukan mendorong, para jagal untuk menebas batang leher mereka (Aleida, 2019).

Dua kutipan dalam cerpen ADKPTN di atas, digambarkan oleh tokoh $\mathrm{Aku}$ bersama Istrinya yang merasakan dampak dari kekuasaan. Mereka terang menyatakan sebagai kekuasaan yang tidak memiliki hati dan zalim. Hak rakyat untuk mendapat perlindungan tidak terwujud dengan baik. Oleh karena itu, berada dalam keadaan terdesak, membuat mereka tidak menduga, bahwa pada diri mereka, ada kecerdasan yang tiba-tiba muncul demi mampu beradaptasi di tempat dan suasana baru.

May (2019) kembali menegaskan, bahwa kemampuan membenci atau marah adalah tanda seseorang masih memiliki potensi-potensi batiniah yang dapat digunakan untuk melawan orang-orang yang menindas. Bagi tokoh Aku dan Istri, wujud perlawanan yang bisa mereka lakukan adalah membenci dan marah pada rezim. Mereka merelakan paspor mereka dicabut dari negara asal mereka demi menjauh dari kejamnya penindasan dan pembungkaman. 


\section{KESIMPULAN}

Berdasarkan hasil dan pembahasan dalam penelitian ini, dapat disimpulkan, bahwa kebencian dan amarah tokoh eksil dalam dua cerpen karya Martin Aleida berdasarkan teori psikologi eksistensial model May terbagi dalam dua kategori. Pertama, kebencian dan amarah kepada rezim. Kedua, kebencian dan amarah kepada diri. Dalam cerpen Tanah Air, dua kategori tersebut hadir mengukuhkan rangkaian peristiwa dan dalam cerpen Asmara dan Kematian di Perbatasan Tiga Negara, hanya satu kategori yang muncul membangun peristiwa. Sehingga, tokoh eksil dominan memperlihatkan eksistensinya dengan menunjukkan kebencian dan amarah kepada rezim.

Peneliti ingin menyampaikan beberapa saran berdasarkan kesimpulan di atas. Teori psikologi eksistensial May dengan melihat aspek kebencian dan amarah tokoh eksil dapat menjadi referensi bagi mahasiswa yang ingin mengetahui dan mendalami penelitian psikologi sastra yang spesifik. Selain itu, penelitian ini bisa menjadi petunjuk bagi peneliti lain yang hendak menggunakan teori psikologi eksistensial untuk menganalisis tokoh, khususnya tokoh yang dilabeli dalam karya sastra.

\section{DAFTAR PUSTAKA}

Ahmadi, Anas. 2019. Metode Penelitian Sastra Perspektif Monodisipliner dan Interdisipliner. Gresik: Penerbit Graniti.

Aleida, Martin. 2017. Tanah Air yang Hilang. Jakarta: Penerbit Buku Kompas.

Aleida, Martin. 2019. Kata-kata Membasuh Luka. Jakarta: Penerbit Buku Kompas.
Aminuddin. 1995. Pengantar Apresiasi Karya Sastra. Bandung: Sinar Baru Algesindo.

Darma, Budi. 2019. Pengantar Teori Sastra. Jakarta: Penerbit Buku Kompas.

Faruk. 2012. Pengantar Sosiologi Sastra: Dari Strukturalisme Genetik sampai Post-Modernisme. Yogyakarta: Pustaka Pelajar.

Hasyim, M., Prasuri Kuswarini, P., Kaharuddin. 2020. Semiotic Model for Equivalence and NonEquivalence in Translation. Humanities \& Social Sciences Reviews. 8 (3), 381-391.

Hikma, Nur. 2015. “Aspek Psikologis Tokoh Utama dalam Novel Sepatu Dahlan Karya Khrisna Pabichara: Kajian Psikologi Humanistik Abraham Maslow". Jurnal Humanika Universitas Halu Oleo. Volume 3. No. 15.

Intan, Tania. 2018. Narator Sebagai Penyampai Kritik Sosial Dalam Novel Moha Le Fou Moha Le Sage Karya Tahar Ben Jelloun. Jurnal Ilmu Budaya. 6 (2), 207-220

Loir, Henri Chambert. 2018. Sastra dan Sejarah Indonesia. Jakarta: Kepustakaan Populer Gramedia.

May, Rollo. 2019. Manusia Mencari Dirinya. Diterjemahkan oleh Afthonul Afif. Yogyakarta: Basabasi.

May, Rollo. et al. 1958. Existence, A New Dimension in Psychiatry and Psychology. New York: Basic Books.

Minderop, Albertine. 2010. Psikologi Sastra. Jakarta: Buku Obor.

Misiak, Henryk dan Virginia Staudt Sexton. 2009. Psikologi Fenomenologi, Eksistensial, dan Humanistik. Diterjemahkan oleh E. Koswara. Bandung: Refika Aditama. 
Mudzakkir, Amin. 2013. "Eksil Indonesia dan Nasionalisme Kita". Seminar PSDR-LIPI, Jakarta: 3 Desember 2013. Hal. 1-15.

Mudzakkir, Amin. 2015. "Living in Exile: The Indonesian Political Victims in The Netherlands". Jurnal Masyarakat dan Budaya P2KKLIPI. Volume 17. No. 2.

Rokhmansyah, Alfian. 2014. Studi dan Pengkajian Sastra, Perkenalan Awal Terhadap Ilmu Sastra. Yogyakarta: Graha Ilmu.

Sayuti, Suminto A. 2017. Berkenalan dengan Prosa Fiksi. Yogyakarta: Cantrik Pustaka.

Situmorang, Saut. 2014. Sastra Eksil, Sastra Rantau. https://boemipoetra. wordpress.com/2014/09/16/sastraeksil-sastra-rantau-2/. Diunduh pada tanggal 31 Agustus 2019 pukul 18.19 WITA.

Stanton, Robert. 2007. Teori Fiksi. Diterjemahan oleh Sugihastuti dan Rossi Abi Al Irsyad. Yogyakarta: Pustaka Pelajar.

Wellek, Rene dan Austin Warren. 2014. Teori Kesusastraan. Diterjemahkan oleh Melani Budianta. Jakarta: Gramedia Pustaka Utama.

Yin, Robert K. 2000. Case Study Research: Design and Methods. Diterjemahkan oleh M. Djauzi Mudzakir. Jakarta: PT Raja Grafindo Persada. 